\title{
Predispositions and symptoms of Agrilus borer attack in declining oak trees
}

\author{
Dries VANSTEENKISTE ${ }^{\mathrm{a} *}$, Luc TIRRY ${ }^{\mathrm{b}}$, Joris VAN ACKER ${ }^{\mathrm{a}}$, Marc STEVENS $^{\mathrm{a}}$ \\ a Laboratory of Wood Biology and Technology, Faculty of Agricultural and Applied Biological Sciences, Ghent University, Coupure Links 653, \\ 9000 Gent, Belgium \\ b Laboratory of Agrozoology, Faculty of Agricultural and Applied Biological Sciences, Ghent University, Coupure Links 653, 9000 Gent, Belgium
}

(Received 13 August 2003; accepted 6 April 2004)

\begin{abstract}
This paper presents results of a semi-quantitative study on the role of Agrilus biguttatus F. in oak decline in Belgium. Larvae of this insect breed in living subcortical tissues of European oak. Several factors favouring attacks are discussed, among which the overall health condition and the local physical and biochemical status of the host tree. Larvae, feeding galleries, pupae, imago and D-shaped emergence-holes of $A$. biguttatus were observed exclusively in declining and recently dead oaks. Attacks start in the south-facing, sun-exposed parts of the subcrown stem, with a preference for thicker-barked trees or similar areas within declining trees. The feeding of early larval stages induces subcortical necrosis and longitudinal bark cracking. The more destructive tunnelling of advanced larval stages cuts functional vessels and phloem elements, which enhances the decline. In conclusion, effects on wood quality and suitable control options are discussed.
\end{abstract}

\section{decline / Quercus spp. / Agrilus biguttatus F. / symptoms / predisposition}

\begin{abstract}
Résumé - Prédispositions et symptômes d'attaques d'Agrilus dans des chênes dépérissants. Nous présentons les résultats d'une étude semi-quantitative portant sur le rôle du Coléoptère Agrilus biguttatus F. dans le dépérissement de chênes en Belgique. Les larves de cet insecte s'attaquent au xylème et au phloème vivants. Plusieurs facteurs favorisant les attaques sont discutés. Parmi ces facteurs, la santé générale et les états physiques et biochimiques locaux de l'arbre hôte semblent être décisifs pour permettre sa colonisation. Des larves, des galeries souscorticales, des nymphes, des adultes et des trous d'émergence en forme de D d'A. biguttatus ont été trouvés uniquement dans des chênes dépérissants ou morts récemment. Les attaques commencent dans les parties ensoleillées de l'arbre situées en dessous de la couronne et exposées vers le sud, avec une préférence pour des arbres ou des zones de l'arbre qui sont affaiblis et qui ont une écorce épaisse. Les larves juvéniles endommagent le cambium vasculaire et provoquent ainsi une fissuration longitudinale dans l'écorce. Les galeries des stades larvaires plus avancés coupent des éléments de xylème et de phloème fonctionnels et stimulent ainsi le dépérissement. Pour conclure, les effets sur la qualité du bois et des mesures de contrôle adéquates sont discutés.
\end{abstract}

dépérissement / Quercus spp. / Agrilus biguttatus F. / symptômes / prédisposition

\section{INTRODUCTION}

In the last decades, oak decline has been observed in numerous countries of Europe and North America [12, 22, 27, 36]. In Belgium, the earliest reports on oak decline date back to the beginning of the 20th century. The features observed at that time were similar to the present-day decline symptoms [17, 25]. Oak decline can be of an acute or a chronic nature but always results in crown dieback and often in reduced radial growth. In spring, buds of affected trees fail to break or wilt shortly after budbreak and often smaller leaves are formed. Leaf chlorosis and curling, along with precocious leaf and twig shedding and changes in branching habit may be observed. Many affected trees respond by epicormic sprouting on the bole and larger branches. Another frequently observed symptom is a black exudation from longitudinal bark lesions [9]. Oaks showing such symptoms are later invaded by secondary parasites, both fungi and insects, which enhance the decline [18, 27, 35]. Final symptoms of oak decline reflect the root killing and girdling effects of these organisms. As dieback and reduced growth continue, larger branches die and finally give the tree a stag-headed appearance. Towards the end of the process, decay organisms invade the deteriorating sapwood and bark tissues, which ultimately results in loosening of the dead bark. The whole process may be characterised by a variable combination of symptoms and evolves either rapidly, with trees apparently being killed

\footnotetext{
* Corresponding author: Dries.Vansteenkiste@UGent.be
} 
in a single growing-season, or slowly, taking several years before the trees die. However, trees that once were declining have been observed to recover, especially those suffering of chronic decline.

Many authors believe that a regionally varying complex of temporally and spatially interrelated biotic and abiotic factors causes the gradual or rapid decrease of oak vitality [6]. Decline models usually structure this complex set of factors by making a distinction between predisposing, inciting and contributing factors. According to these models, oak trees can be genetically, environmentally or anthropogenically predisposed to damage by inciting stress factors such as drought, waterlogging, frost, or by pests such as defoliating insects [18, 31, 35]. Such primarily damaged trees can then be weakened further by climatic extremes, or be invaded and killed by insects and micro-organisms that cannot successfully attack healthy trees [36]. The girdling caused by larvae of Agrilus biguttatus F. (Coleoptera: Buprestidae) is considered to be a contributory factor, although it eventually may kill oaks [14, 17, 27]. Agrilus spp. have been linked to root infections by Collybia fusipes and presence of Phytophthora in Q. robur [4] and have been suspected of transmitting pathogenic fungi from infected to healthy trees, which raised questions about their secondary role [20,30].

Agrilus biguttatus F. spends most of its life underneath the thick bark of European Quercus spp. Its life cycle is usually completed in two years; exceptionally, it takes only one year to reach maturity. The white eggs are deposited as small clusters in bark crevices in May-June-July. After one to two weeks, the eggs hatch; the larvae immediately burrow through the bark and start feeding on the inner bark, the cambial layer and the outer sapwood, during the warm months of the year of oviposition and, in some cases, of the following year. If colonisation is successful, numerous inter-crossing galleries are formed which steadily become larger, from 0.5 to $5 \mathrm{~mm}$ wide, and longer, up to 1.5 meter long. Larval hibernation (one or two winters) and pupation takes place in individual cells in the outer bark, in a doubled-over position. Pupation occurs in the spring (from April to May) of the third, sometimes already of the second calendar year. Adult beetles emerge from characteristic D-shaped holes in May-June-July [21, 26, 29]. Emergenceholes of other oak-infesting wood-borers are circular or lensshaped [10].

Agrilus is difficult to study in situ because of the subcortical way of life of the larvae. Apart from the investigations of Hartmann et al. $[13,14]$, European case studies dealing with the ecology of this insect and its role in oak decline are scanty. This paper presents results of a multidisciplinary research project on oak decline in Flanders which started in 1996. Co-ordinated investigations were set up to evaluate the role of soil and stand characteristics, climate, micro-organisms, and the effects of oak decline on wood anatomy and quality. Laboratory and field observations on experimental logs and standing trees led to a parallel semi-quantitative study on Agrilus biguttatus. The main objectives of this particular study were to assess the role of this borer in the regional decline process, to evaluate wood quality effects and, subsequently, to formulate adequate control measures.

\section{MATERIALS AND METHODS}

\subsection{Site selection}

Two research sites were selected in the lowland region of Belgium (Flanders), at a distance of approximately $50 \mathrm{~km}$ from each other, where alarming oak decline had been observed in the past two decades. The first site is the 180 ha Buggenhout forest $\left(51^{\circ} 0\right.$ ' $00^{\prime \prime}$ N, $4^{\circ} 13$ ' 30 ' E) where oak stands consist purely of sessile oak, Quercus petraea (Matt.) Liebl., of certified provenance. Beech stands (Fagus sylvatica L.) make up another significant portion of this forest. The second location is the larger, over 4000 ha forest formation SE of Brussels, the Soignes forest $\left(50^{\circ} 45^{\prime} 00^{\prime}\right.$ ' N, $\left.4^{\circ} 25^{\prime} 30^{\prime \prime} \mathrm{E}\right)$. There, oak stands consist either of pure or mixed stands of $Q$. petraea and $Q$. robur L., or of oak mixed with beech. The Soignes forest has rich loamy soils; those of Buggenhout forest are sandy with a poorer mineral composition. The relief is overall flat in Buggenhout; some of the study sites in the Soignes forest are situated on light slopes.

\subsection{Preliminary field study on standing trees}

At both sites, 48 dominant mature oaks of different vitality were selected, based on crown transparency, leaf discoloration, crown dieback, bark condition and epicormic sprouting which had been estimated visually during the August 1996 tree vitality survey, according to the methods described in the ICP Forests manual [33]. Trees showing over $25 \%$ leaf loss were considered declining. Hence, 96 trees were selected, 48 vital and 48 declining, distributed over six plots in Buggenhout (eight trees per plot) and seven plots in Soignes (different number of trees per plot, ranging from 4 to 14); each plot consisted of an equal number of healthy-looking and declining oaks. At the end of June 1997, a preliminary survey was made of insect emergence-holes and longitudinal bark cracks through qualitative observations on the lower bole of all 96 oaks.

\subsection{Investigations on felled trees}

In addition to the 96 oaks of the field study, 12 oaks (six per site) of different vitality have been felled in October 1996 to study the subcortical damage and distribution of borer insects in detail. Starting at $1 \mathrm{~m}$ above ground-level, stem disks about $10 \mathrm{~cm}$ thick were sampled at $1 \mathrm{~m}$ intervals, including stem as well as crown wood. From the lower one meter of each stem, two logs of $0.5 \mathrm{~m}$ in length were extracted. The position of the magnetic north was marked on every sample. The logs and disks were stored outdoors throughout the winter of 19961997.

Basic dendrometrical data of the 12 oaks are listed in Table I. Mean values, standard deviations and significant differences of the dendrometrical data are also given in Table I. The six oaks from Soignes were identified as $Q$. robur. The trees were significantly younger but nevertheless taller in Soignes compared to Buggenhout. However, circumference did not differ significantly between the two sites. The crown transparency percentages in table I do not refer to insect defoliation but to symptomatic leaf loss. They were estimated immediately prior to felling, using 5\% classes [33]. Average leaf loss was comparable in both forests. Maximum bark thickness was measured with an electronic slide ruler up to $0.01 \mathrm{~mm}$, at 20 points equally distributed around the stem's circumference, on the dried stem-disks sampled at $1 \mathrm{~m}$ height. Tree age was determined with a LINTAB ${ }^{\circledR}$ on the same disks.

In July 1997, 220 stem-disks were screened for bark cracks, subcortical wounds and emergence-holes. On each disk, the bark was chiselled off, broken into smaller pieces and examined for larvae, pupae, pupal cells or adult beetles. Both transversal sides of each disk were examined to find (overgrown) wound areas. The exposed subcortical 
Table I. Basic dendrometrical data, averages and standard deviations (in between brackets) of six sessile oaks $(Q$. petraea) from Buggenhout and six pedunculate oaks $(Q$. robur $)$ from Soignes. Significant differences $(t$-test $)$ are given at probability levels $0.05^{*}, 0.01^{* *}, 0.001^{* * *}$ or n.s. $=$ not significantly different.

\begin{tabular}{|c|c|c|c|c|c|c|}
\hline \multicolumn{2}{|c|}{$\begin{array}{l}\text { Site and } \\
\text { tree number }\end{array}$} & $\begin{array}{l}\text { Circumference } \\
\text { at } 1.50 \mathrm{~m}(\mathrm{~cm})\end{array}$ & $\begin{array}{l}\text { Total height } \\
\text { (m) }\end{array}$ & $\begin{array}{c}\text { Age at } 1 \mathrm{~m} \\
\text { (years) }\end{array}$ & $\begin{array}{c}\text { Leaf loss } \\
(\%)\end{array}$ & $\begin{array}{l}\text { Bark thickness } \\
\text { at } 1.50 \mathrm{~m}(\mathrm{~mm})\end{array}$ \\
\hline \multirow{6}{*}{ 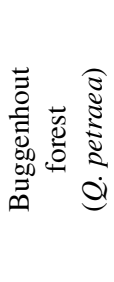 } & I & 125 & 26.5 & 120 & 35 & 13.80 \\
\hline & II & 130 & 21.5 & 125 & 100 & 14.84 \\
\hline & III & 122 & 24.0 & 127 & 20 & 11.42 \\
\hline & IV & 128 & 20.8 & 153 & 85 & 14.44 \\
\hline & V & 120 & 19.8 & 146 & 65 & 14.78 \\
\hline & VI & 120 & 22.0 & 148 & 15 & 10.29 \\
\hline \multirow{6}{*}{ 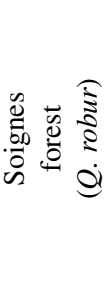 } & VII & 125 & 31.3 & 98 & 100 & 11.25 \\
\hline & VIII & 130 & 26.5 & 104 & 25 & 9.93 \\
\hline & IX & 116 & 30.0 & 92 & 85 & 11.34 \\
\hline & $\mathrm{X}$ & 111 & 27.4 & 89 & 65 & 11.10 \\
\hline & XI & 122 & 25.8 & 93 & 35 & 10.95 \\
\hline & XII & 122 & 31.1 & 116 & 45 & 8.21 \\
\hline \multicolumn{2}{|c|}{ Q. petraea } & $124(4.2)$ & $22.4(2.4)$ & 137 (5.7) & $53(35)$ & $13.26(1.93)$ \\
\hline \multicolumn{2}{|c|}{ Q. robur } & $121(6.7)$ & $28.7(2.4)$ & $99(4.1)$ & $59(29)$ & $10.46(1.21)$ \\
\hline \multicolumn{2}{|c|}{$t$-test } & n.s. & $* *$ & $* * *$ & n.s. & $*$ \\
\hline
\end{tabular}

tissues were also examined to assess the presence of larvae and tunnels. Tunnels were scored as wide when over $1 \mathrm{~mm}$ in width. The subcortical and overgrown wounds were examined microscopically, after sanding the transversal surfaces of the disks. Less thorough observations have been made on the bark of nearly $2001-\mathrm{m}$ logs remaining in the forests.

In order to quantify the degree of borer attack, an infestation index was calculated. This index takes into account the distribution of tunnels, wounds and emergence-holes within the tree and ranges from 0 (no infestation) to 10 (heavy infestation). It is a weighted average of the presence (1) or absence (0) of these features in the lower (L) or upper (U) parts of the trunk, respectively below and above the $10 \mathrm{~m}$ height level, using the arbitrarily chosen numbers (1 to 4 ) given at the bottom of table II as weight factors. Features observed in the upper parts were systematically attributed a heavier factor than in the lower parts, since - according to literature and our field observations - they indicate a more advanced stage of borer attack. Moreover, since the presence of overgrown wounds indicates a tree has managed to recover from earlier attacks while bark wounds suggest recent or ongoing attacks, the latter were considered as more severe symptoms than overgrown wounds and given heavier weights.

\section{RESULTS}

\subsection{Preliminary field observations}

Non-destructive screening of the lower stem parts at the two sites indicated that all of the nearly or presumably dead oaks (four trees with over $90 \%$ leaf loss) showed numerous emergence-holes of $A$. biguttatus. In such trees, large stem areas with detached bark were observed, showing signs of desiccation and fungal decomposition. Removal of loose bark revealed sharpedged feeding galleries of A. biguttatus along with larger tunnels about $5 \mathrm{~mm}$ wide made by larvae of Longhorned beetles
(Cerambycidae). D-shaped emergence-holes were not observed in trees that showed less than 50\% leaf loss; this corresponds to 85 out of 96 trees surveyed. When present in high numbers (more than 20), emergence-holes were distributed independently of compass direction. In cases of low incidence (less than 5), the emergence-holes were located predominantly on bark facing south. Trees showing more than 50\% leaf loss (i.e. 11 trees) displayed patches where the outer dead bark-scales had been removed, disclosing the brown-red inner-bark. Longitudinal bark cracks of 5 to $10 \mathrm{~cm}$ long - often marked by dark exudations - were observed on relatively healthy trees as well as on clearly damaged trees. No adults of A. biguttatus were detected.

Most of the observations made on the standing oaks were confirmed when superficially examining the remaining logs $( \pm 200)$ of the 12 felled trees left in the forest throughout the winter of 1996-1997. In this material, bark-cracks were found confined to trunk portions below the crown base. Upon removal of loosened bark in logs of previously declining oaks, Cerambycid- and Buprestid-type galleries and much powdery decay material appeared in large discoloured necrotic areas. Towards crown and stem base, detached areas were narrower. The bark was found still firmly attached, towards the boundaries of these necrotic areas. The crown portions did not show loosened bark. Agrilus larvae and D-shaped emergence-holes were encountered in the bark of the lower logs. However, neither pupae nor adult insects were found. Sapwood borer activity was abundant in all $\log$ (Scolytidae - species not determined).

\subsection{Laboratory examination of woody material from felled trees}

Around mid-June 1997, A. biguttatus beetles started to emerge from the butt-end logs of trees II and VII. A closer 

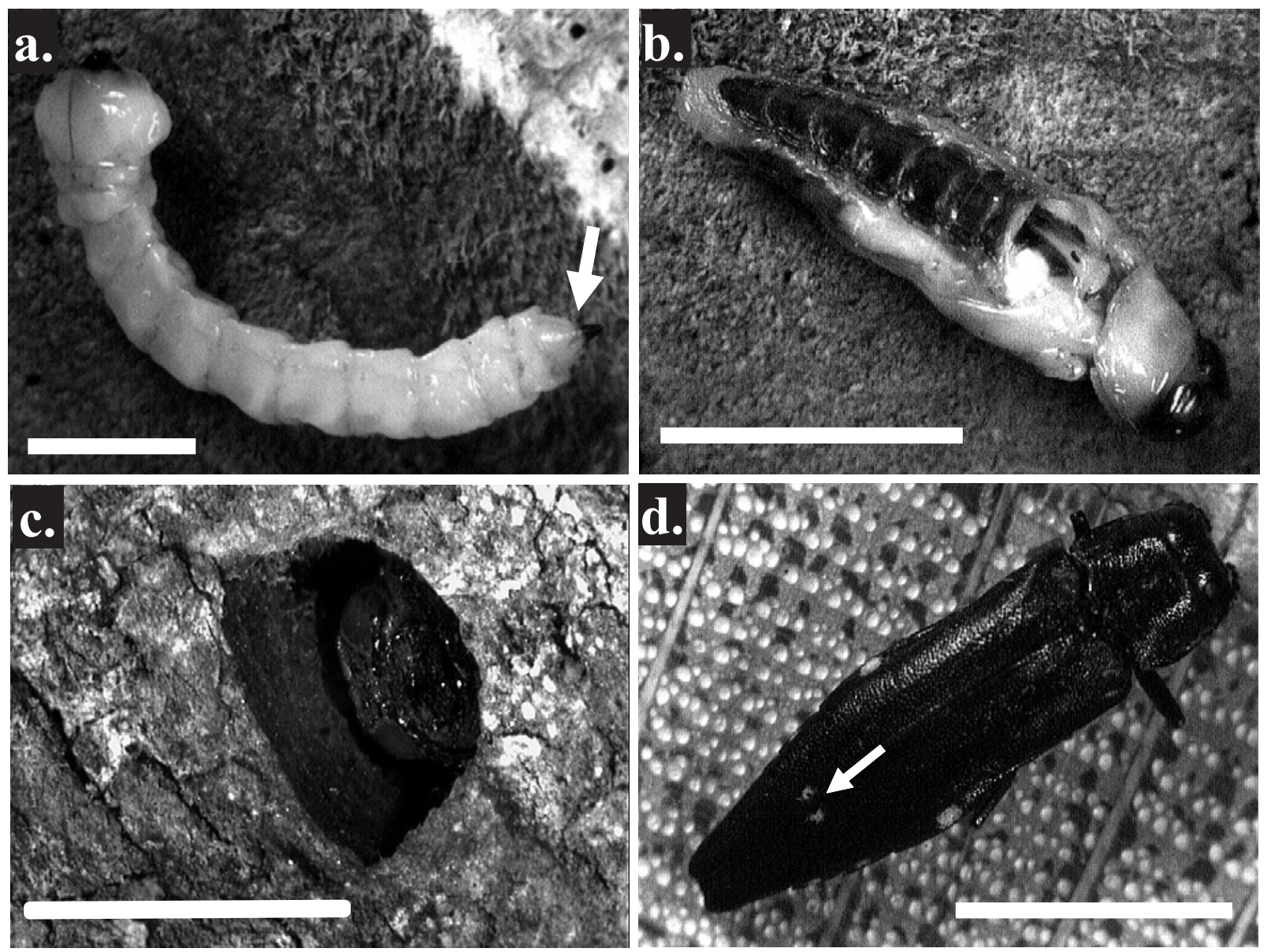

Figure 1. Morphology and characteristic stages of Agrilus biguttatus F.: (a) Almost full-grown larva with slender body and large prothorax; the white arrow indicates the dark pincers at the tip of the abdomen; (b) Pupa found in the outer bark; (c) Typical D-shaped exit-hole; (d) Adult insect of approximately $1.2 \mathrm{~cm}$ long; the white arrow points to the characteristic white dots. The white scale-bar is $5 \mathrm{~mm}$.

inspection of the outer and inner bark revealed not only the presence of living adults of Agrilus in pupal cells, but also of larvae, pupae and D-shaped emergence-holes. Photographs of the characteristic developmental stages encountered at that time are shown in Figure 1. All larvae had reached the final larval stage, considering their length of over $2 \mathrm{~cm}$. The majority of the adult beetles was approximately $1 \mathrm{~cm}$ long and had a metallic dark-blue colour, but some were slightly longer and darkgreen coloured. Within and underneath the bark of the same logs, larvae of longhorned beetles were also present. Morphological differences allowed distinguishing these easily from Agrilus larvae. The tunnels of A. biguttatus are confined to a thin cambial layer and sharper edged than those resulting from the more destructive actions of Cerambycidae-larvae in the inner-bark. All logs contained Ambrosia beetles (Scolytidae species not determined) whose galleries extended deep into the sapwood.

The features observed on the disks are given in Table II and Figures 3 to 5 . Inspection of the bark surface revealed the presence of longitudinal cracks in 65 out of 220 stem disks, mainly in sectors opposed to the magnetic north. The bark tissues bor- dering such cracks appeared brown discoloured, either wet or dry. A relatively large irregular-shaped patch of dead woody tissue of about 8 to $10 \mathrm{~cm}$ high and 2 to $5 \mathrm{~cm}$ wide was present underneath the ruptured bark. Cambial activity apparently had ceased in such areas. However, the dry or still moist wood was partly or completely overgrown by white-coloured wound tissue protruding from the border of the necrotic area.

The cross-sections of 34 disks displayed interior cicatrices, appearing as T-shaped scars of 1 to $5 \mathrm{~cm}$ wide tangentially and several $\mathrm{mm}$ long radially, overgrown by wound tissue and, subsequently, by normal wood. When bark and callus were removed from recently formed wounds, hereby exposing the area where cambial activity had ceased, we found sinuous discoloured lines of less than $1 \mathrm{~mm}$ wide in 65 disks, which we identified as tunnels made by young larvae of A. biguttatus. Debarking of all stem disks revealed larger feeding galleries attributable with certainty to this borer since they could be traced back to the necroses found beneath bark cracks. Large tunnels $(\varnothing>1 \mathrm{~mm})$ were observed in 31 disks, mainly in the more severely damaged oaks (II, IV and VII). Feeding tunnels were absent in trees having less than $25 \%$ leaf loss (i.e. oaks 
Table II. Presence (1) or absence (0) of features indicating Agrilus-attack in stem-disks taken from below (L) and above (U) the $10 \mathrm{~m}$ height level. The Agrilus infestation index is a weighted mean calculated by using the arbitrary weight factors given at the bottom of the table.

\begin{tabular}{|c|c|c|c|c|c|c|c|c|c|c|c|c|}
\hline \multirow{3}{*}{\multicolumn{2}{|c|}{$\begin{array}{c}\text { Site } \\
\text { and } \\
\text { tree number }\end{array}$}} & \multirow{2}{*}{\multicolumn{2}{|c|}{$\begin{array}{l}\text { Narrow tunnels } \\
(\varnothing \leq 1 \mathrm{~mm})\end{array}$}} & \multirow{2}{*}{\multicolumn{2}{|c|}{$\begin{array}{l}\text { Wide tunnels } \\
(\varnothing>1 \mathrm{~mm})\end{array}$}} & \multicolumn{4}{|c|}{ Wounds } & \multirow{2}{*}{\multicolumn{2}{|c|}{$\begin{array}{l}\text { D-shaped } \\
\text { exit-holes }\end{array}$}} & \multirow{3}{*}{$\begin{array}{c}\text { Agrilus } \\
\text { infestation } \\
\text { index }\end{array}$} \\
\hline & & & & & & \multicolumn{2}{|c|}{ bark } & \multicolumn{2}{|c|}{ overgrown } & & & \\
\hline & & $\mathrm{L}$ & $\mathrm{U}$ & $\mathrm{L}$ & $\mathrm{U}$ & $\mathrm{L}$ & $\mathrm{U}$ & $\mathrm{L}$ & $\mathrm{U}$ & $\mathrm{L}$ & $\mathrm{U}$ & \\
\hline \multirow{6}{*}{ 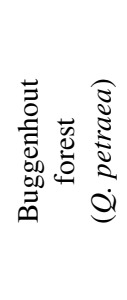 } & I & 1 & 0 & 0 & 0 & 1 & 0 & 1 & 0 & 0 & 0 & 2.4 \\
\hline & II & 1 & 1 & 1 & 1 & 1 & 1 & 1 & 0 & 1 & 1 & 9.2 \\
\hline & III & 0 & 0 & 0 & 0 & 0 & 0 & 0 & 0 & 0 & 0 & 0.0 \\
\hline & IV & 1 & 1 & 1 & 0 & 1 & 1 & 0 & 0 & 1 & 0 & 5.2 \\
\hline & V & 1 & 1 & 0 & 0 & 1 & 1 & 1 & 1 & 0 & 0 & 6.0 \\
\hline & VI & 0 & 0 & 0 & 0 & 0 & 0 & 0 & 0 & 0 & 0 & 0.0 \\
\hline \multirow{6}{*}{ 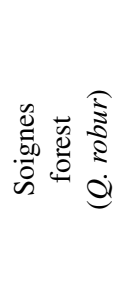 } & VII & 1 & 1 & 1 & 0 & 1 & 1 & 1 & 1 & 1 & 0 & 7.6 \\
\hline & VIII & 0 & 0 & 0 & 0 & 0 & 0 & 0 & 0 & 0 & 0 & 0.0 \\
\hline & IX & 1 & 1 & 1 & 0 & 1 & 1 & 1 & 1 & 0 & 0 & 6.8 \\
\hline & $X$ & 1 & 1 & 1 & 0 & 1 & 1 & 1 & 0 & 1 & 0 & 4.8 \\
\hline & XI & 1 & 0 & 1 & 0 & 1 & 0 & 1 & 0 & 1 & 0 & 4.0 \\
\hline & XII & 0 & 0 & 0 & 0 & 0 & 0 & 0 & 0 & 0 & 0 & 0.0 \\
\hline \multicolumn{2}{|c|}{ Weight factor } & 2 & 3 & 2 & 3 & 3 & 4 & 1 & 2 & 2 & 3 & - \\
\hline
\end{tabular}

III, VI and VIII; Tab. II). No larvae, pupae or adult insects were found. This suggests that the D-shaped emergence-holes observed on the bark of 12 disks might have been present prior to felling and that larval development is interrupted in stem-disks.

The average infestation indices of the two sites (and species) were not significantly different: $3.80(\mathrm{~s}=3.65)$ for $Q$. petraea and 3.86 ( $\mathrm{s}=3.26)$ for $Q$. robur. The infestation index (Tab. II) correlates positively with leaf loss (Tab. I): for the 12 felled trees, an adjusted linear $R^{2}$ of $0.827^{* * *}$ was obtained. The same relationship yields an $R^{2}$ of $0.923^{* * *}$ respectively $0.756^{*}$ when the sessile and the pedunculate oaks are considered separately. Hence, as had been observed during the field study, leaf loss tends to increase with increasing degree of infestation (Fig. 2). One pedunculate oak with $45 \%$ leaf loss (tree XII) clearly deviates from the relationship.

The link observed between the infestation index and average bark thickness suggests there is a threshold thickness, around $10 \mathrm{~mm}$ in $Q$. robur and $13 \mathrm{~mm}$ in Q. petraea (Fig. 2), above which a tree becomes a suitable host for Agrilus. Significant positive correlations were obtained between bark thickness and the infestation index. The adjusted linear $R^{2}$ was $0.715^{*}$ for the sessile oaks, and $0.660^{*}$ for the pedunculate oaks. The bark of the pedunculate oaks was significantly thinner than that of the sessile oaks we studied (averages are $10.5 \mathrm{~mm}$ and $13.3 \mathrm{~mm}$ respectively, see Tab. I).

Comparison of the incidences of D-shaped emergenceholes, small and large feeding tunnels, and wounds in the lower stem (132 counts) with those observed in the upper stem (70 counts) indicate that attacks by A. biguttatus start in the lower parts of the trunk, i.e. below the $10 \mathrm{~m}$ level and below the crown base. No evidence was found of A. biguttatus in the crown area, except in the (nearly) dead trees.

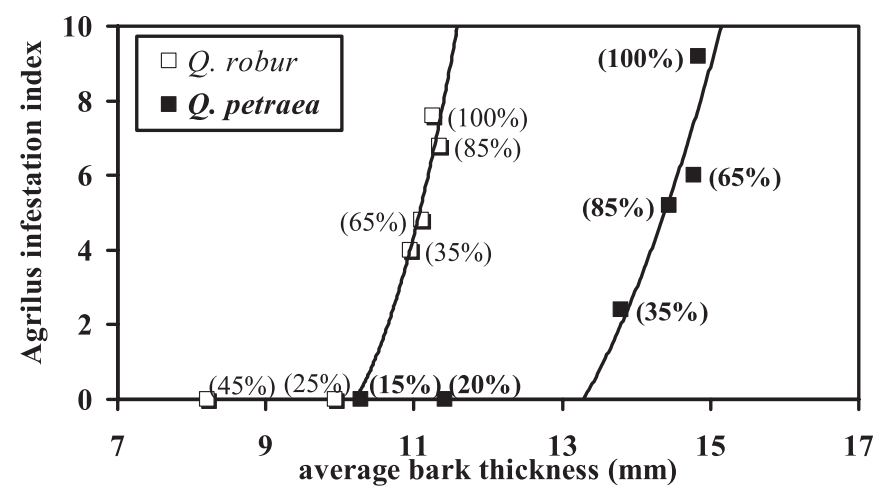

Figure 2. Relationship between the average bark thickness (in $\mathrm{mm}$ ), the calculated Agrilus infestation index and the estimated leaf loss (in $\%)$ of six pedunculate $(\square)$ and six sessile oaks ( $\square)$.

\section{DISCUSSION}

Although Schopf [28] found no link between host condition and incidence of related Agrilus species, A. angustulus and $A$. sulcicollis, many authors have shown that $A$. biguttatus and $A$. bilineatus (in N-America) attack only stressed and declining oaks $[5,7,8,10,11,14,21,22]$. In this study, a positive relationship was found between the degrees of Agrilus attack and leaf loss (Fig. 2). The factors that predisposed the oak trees to borer attack were not apparent. Several biotic or environmental stress factors could be involved [8].

The results in Figure 2 and our field observations indicate that a leaf loss of 20 to $30 \%$ has to be exceeded before Agrilusattack becomes apparent in both oak species. Hartmann and 
Kontzog [14] determined the leaf loss threshold at $25 \%$. Beyond this level, leaf loss correlates positively with degree of Agrilus-attack. The weaker relation found for the pedunculate oaks might be due to the vigorous epicormic sprouting in the oaks IX, X and XII. Epicormic shoots may compensate for reduced crown productivity. Tree XII which had an estimated crown transparency of 45\%, showed no evidence of Agrilusattack. Hence, leaf loss not always reflects the internal vitality of a tree. Moreover, not necessarily all the declining trees within or near an infested stand will be attacked by this borer, as had been observed already in the field study.

Since Agrilus spp. have been studied only in connection with declining oaks, it is not known whether borer populations will become extinct or if healthy oaks or stressed trees of other species will be attacked when suitable hosts are lacking. The number of suitable host trees probably regulates the borer insect population density at the forest ecosystem level. At the tree level, suitability seems to depend upon a complex of stress-induced physical and physiological changes. Mattson and Haack [19] hypothesized that some bark- and wood-boring species identify suitable hosts via drought-induced ultrasonic emissions produced as a result of water columns breaking in the xylem of stressed trees. Susceptibility to borer attack and host tree specificity of insects in general may also be related to age-dependent, intra- and interspecific differences in the chemistry of leaves, bark and woody tissues. According to Haack and Benjamin [11], stressed oaks release volatile substances that are attractive to A. bilineatus. Côté and Allen [5] mention alcoholic substances, resulting from endophytic, anaerobic fermentation as possible attractants. Specific deterrent compounds might be of equal importance in explaining differences in resistance. Both repellent and attractant compounds are present inside the tree along varying concentration gradients, or compartmentalised [16]. This may explain why the subcortical region colonised by Agrilus sp. does not die uniformly but in patches. Host condition appears to be responsible also, in part, for the variation in time of emergence of Agrilus sp., with development being retarded in hosts that die rapidly or in material that dries out fast [35]. This explains why different developmental stages of $A$. biguttatus could be found simultaneously in the logs of the felled trees. Asynchronous development of subcortical insects has been attributed to within- and between-tree differences in nutritional quality of food, moisture content and temperature [5].

Apart from host condition, it is known that temperature influences the selection of suitable hosts or sites for oviposition by A. biguttatus and A. bilineatus. Warm, dry years generally favour insects' growth and reproduction [10, 27]. Low temperatures, especially in late spring and early autumn, retard or interrupt these processes. These thermophile insects therefore prefer oviposition sites that are exposed to the sun, for instance larger branches in the transparent crown of declining trees [2, 13, 29]. Parmeter et al. [24] reported of beetle galleries in infected branches of wilting bur oaks, presumably made by $A$. bilineatus, but did not investigate the trunks. A. bilineatus appears to start its attacks in the crown of declining oaks and then spreads downwards $[10,11,36]$. According to Block et al. [1], the attacks of $A$. biguttatus also start in the crown. However, Wargo [34] reported that $A$. bilineatus was found only occasionally in the upper branches of declining oaks. Dunbar and
Stephens [7] found few larvae of A. bilineatus in branches; most were encountered in the upper bole. Like Hartmann and Kontzog [14], we found that the crown wood is not attacked by A. biguttatus (Tab. II). Our results indicate that the infestation starts rather at some distance from the crown, i.e. in areas where internal nutritional stress is expected to be higher and resistance to biological attacks is likely to decrease earlier. The attacks start in south-facing, lower stem parts and then proceed upwards and further downwards. Symptoms of Agrilus-attack found in the crown can probably be attributed to mechanical injury, e.g. caused by wind breakage. The type of spreading is valid for both oak species studied.

When considering both oak species separately (Fig. 2), the present study showed that A. biguttatus points its attacks towards thicker-barked declining oaks. The bark of tree XII was the thinnest of all 12 trees studied and, in spite of a considerable leaf loss, this oak showed no evidence of Agrilus-attack. Haack and Acciavatti [10] reported that larvae of A. bilineatus construct pupal chambers in the outer sapwood if the outer bark is too thin. This was not confirmed in our study; all the pupae and adults were found in the outer bark. It seems plausible that a thin bark will limit the construction of pupal chambers. Moreover, a thicker bark offers more protection against drought, frost and predating birds. The bark desquamation we observed on standing trees, presumably made by woodpeckers and treecreepers, illustrates the importance of bark thickness. Bark scaling predators represent a considerable threat to hibernating larvae, pupae and adults of $A$. biguttatus and A. bilineatus. Reduction of the borer population occurs also by predacious beetles and Hymenopteran larval parasitoids [5, 10, 14]. We may assume that for normal development of Agrilus sp., a minimum bark thickness is required. Since the bark of the lower trunk is usually thicker and has a different structure than that of the branches and the upper trunk, at a given tree age, attacks may be expected to start in stem parts below the crown rather than in the crown itself. Likewise, because bark thickness is more or less dependent on cambial age, oak trees should become susceptible to attacks of $A$. biguttatus but from a certain age on. The physical lower limit of bark thickness seems to be around $1 \mathrm{~cm}$ for $A$. biguttatus (Fig. 2). The threshold bark thickness was found to be lower in $Q$. robur $(10.2 \mathrm{~mm}$, compared to $13.3 \mathrm{~mm}$ in $Q$. petraea). This implies that species- and agedependent differences exist in resistance to borer attacks.

The first visible symptom of Agrilus-attack in oaks is the apparition of bark cracks, facultatively accompanied by dark exudation. Hartmann and Blank [13] supposed that the underlying necroses were caused by primary frost damage. This seems unlikely when considering the small size of recent subcortical wounds (a few square $\mathrm{cm}$ ). Cambium that dies of frost is expected to do so in much larger patches of several square decimetres in size. More likely, the desiccation and specific wound reactions that follow upon feeding by Agrilus larvae cause the cambial sheath to die off in small patches. Normally, cicatrices develop at the margins of such necroses (Fig. 3). Cicatrices develop in two stages, the first being the establishment of undifferentiated callus and the second the differentiation of vascular tissue from a new cambium formed within the callus [23]. Due to the local subcortical swelling induced by expanding callus and subsequent normal wood formation, the bark covering necrotic tissue ruptures. Hereupon, the wounds attract secondary 


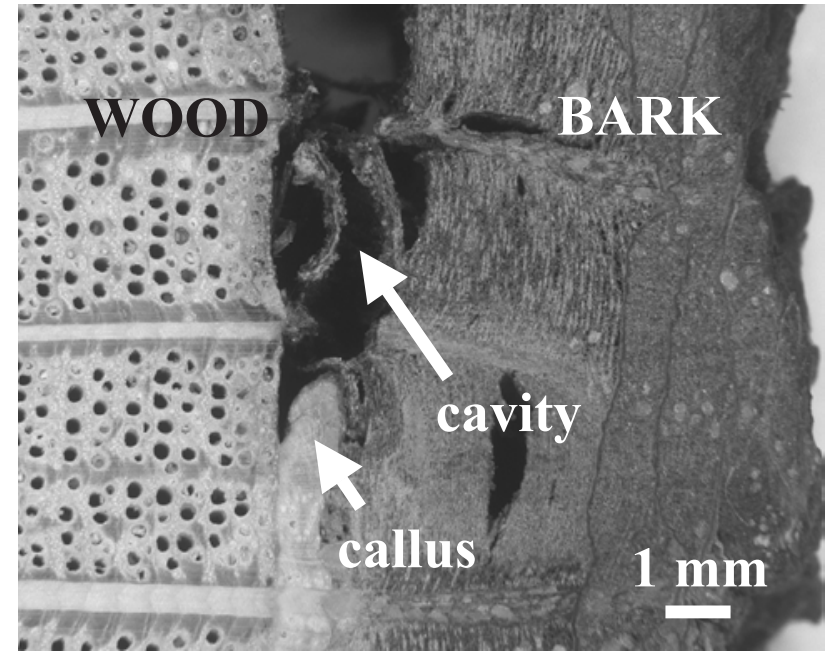

Figure 3. Transversal section of a necrotic area showing the cavity present underneath the ruptured bark and the callus protruding from the border of the killed area.

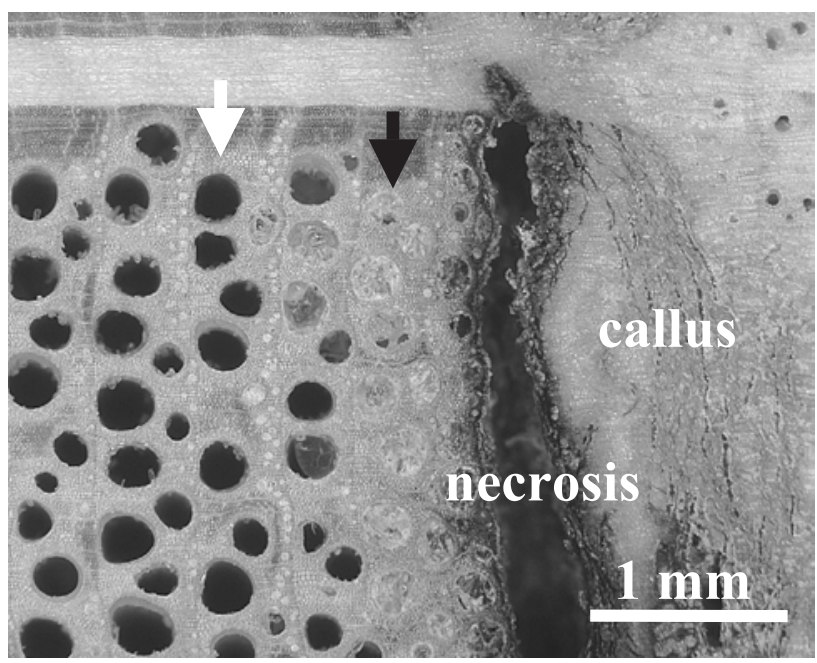

Figure 4. Close-up view in cross-section of a subcortical necrosis overgrown by callus tissue, showing unplugged vessels (below white arrow) and vessels plugged by tyloses (below black arrow).

borers and become suitable infection courts for fungi and bacteria, which initiate decay and induce cellular post-mortem reactions. These processes could be responsible for the "bleeding" symptom, dark exudations oozing out of the bark lesions. In addition, they induce tylosis formation in neighbouring xylem vessels. Necrotic discoloured tissues were found, with extensive tylosis of the earlywood vessels nearby tunnels of $A$. biguttatus (Fig. 4). This could be a controlled reaction against the increase in concentration of toxic excreta within parenchyma cells adjacent to vessels [32]. In oak, tyloses are formed

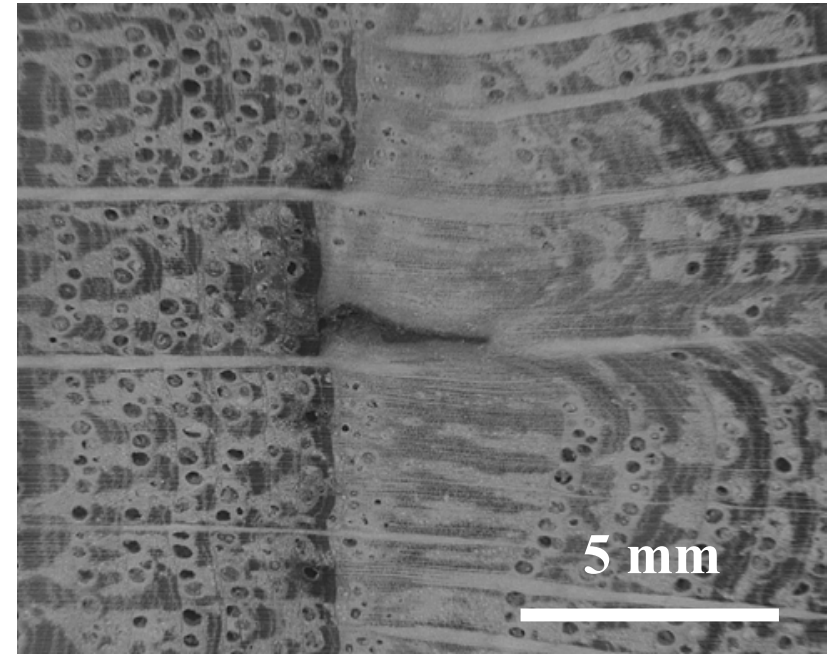

Figure 5. A small overgrown cicatrice viewed in cross-section shows a T-shaped scar.

during heartwood formation and at restricted distances from an injury. Tylosis has been associated also with infections of vascular fungi $[15,24]$.

Vigorous callus formation may be a way of engulfing young Agrilus larvae, since they feed slowly [5, 7, 8, 14, 27]. Hence, the success of the borers' invasion will depend on the number of larvae present and on the rate of callus production. Dunn et al. [8] suggested that oak trees with relatively low winter reserves, which are more likely to be attacked by A. bilineatus the following season, may have insufficient carbohydrate available in early summer to resist stem invasion. Vigorous trees manage to completely heal over their wounds. This results in what is called "T-disease" because distinctive T-shaped scars appear in transverse sections of trees recovered from borer attack (Fig. 5).

If the invasion is not withstood, the larvae continue to grow and create galleries that gradually become wider. The larger larvae of Agrilus sp. cause damage that is physically and physiologically equivalent to that caused by artificial girdling of phloem or xylem. Xylem girdling interrupts the upward movement of water and mineral nutrients from roots to the crown. Phloem girdling cuts the downward flow of assimilates and hormones synthesised in the leaves, hence creating deficiencies in the tissues below the girdle. The removal of extra-cambial tissues does not necessarily cut the downward flow, however, as assimilates appear to be able to some extent to move into the peripheral xylem elements and then downwards [23]. Therefore, a girdle which penetrates the sapwood - like the feeding galleries of Agrilus sp. - is very effective.

Girdling upsets the normal water status and the carbon/nitrogen balance of the tree, with a variety of consequences. Related to this may be the interference with the normal production of hormones, which produces reactions both proximal and distal to the girdle, such as anomalous cambial activity, slowing down of apical and radial growth, premature leaf wilting or abscission, epicormic shoot formation, etc. These reactions have been 
observed in artificially girdled trees and are also typical symptoms of oak decline. The sudden final deterioration after girdling is related to exhaustion of carbohydrates and to the cessation of transpiration [23]. Girdling also enhances desiccation and decomposition of subcortical tissues which allows the invasion of other borers. Cerambycidae, for instance, have been found concurrent with Agrilus in trees having adjacent patches of dead and alive cambium [34]. Agrilus does not infest previously killed areas. The presence of D-shaped emergence-holes therefore indicates that a part of the affected tree is probably dead already [10].

The efficacy of girdling, as a means of killing a tree, will depend on the frequency and intensity of the borer attacks. According to Schwerdtfeger [29], Agrilus-larvae can kill a tree only when present in sufficiently large numbers, i.e. 50 larvae or more. The mortality risk will also depend on the time of girdling (most effective during the period of active growth), on host vigour (cf. cicatrisation), on girdle shape (width, height and depth), on tree size (with long survival being related to a high sapwood/heartwood ratio) and on the species (i.e. associated with the wood anatomy). Tree death may occur within one to three years after the initial attack, yet it may also occur in a single season [11].

The impact of Agrilus feeding on wood quality is insignificant in oak trees attacked for the first time - even if it results in death - because only the outer sapwood is affected and this type of wood is usually rejected in processing. However, trees that have recovered (repeatedly) from attacks will contain overgrown T-shaped wounds (Fig. 5). Apart from the esthetical depreciation, we speculate that these cicatrices make the wood prone to radial and ring-shaking, in accordance with the mechanisms described by Butin and Volger [3]. Successful invasion by $A$. biguttatus is often followed by destructive tunnelling by secondary xylem borers and decay by micro-organisms. Early removal of severely declining and dead trees seems therefore advisable in order to preserve the valuable heartwood. Felled trees should be removed from the forest before adult Agrilus emerge. Sanitary felling will nevertheless not prevent healthy trees that are predisposed to decline from being attacked ultimately by Agrilus. Silvicultural practices should favour species and phenotypes that are naturally adapted to the site, in order to reduce all kinds of predisposition. By promoting the use of truly local provenances - maintaining at the same time high levels of genetic variation [31] - and natural regeneration techniques, a more stable forest ecosystem should result. This approach will require time and more detailed knowledge of the ecophysiological requirements of oaks and of their environment. Future research should focus on the variability of the hydraulic architecture of oaks, especially in terms of vulnerability to hydraulic dysfunction.

Acknowledgements: This work has been financed by the Institute of Forestry and Game Management (IBW - Geraardsbergen, Belgium) of the Ministry of the Flemish Community within the framework of the research projects "Oak decline in Flanders" and "Wood Technology and Wood Quality". We wish to express our gratitude to the Foresters of Buggenhout and Soignes for their technical assistance and to P. Roskams of IBW for helpful discussions.

\section{REFERENCES}

[1] Block J., Fischer H., Wirth P., Die Holzqualität absterbender und abgestorbener Stieleichen, HolzZentralbl. 37/38 (1997) 562-564.

[2] Brauns A., Taschenbuch der Waldinsekten - Grundriss einer terrestrischen Bestandes- und Standort-Entomologie, Gustav Fischer Verlag, Stuttgart - Jena, 1991, pp. 218-222.

[3] Butin H., Volger C., Untersuchungen über die Entstehung von Stamrissen ("Frostrissen") an Eiche, Forstwiss. Centralbl. 101 (1982) 295-303.

[4] Camy C., Delatour C., Marçais B., Relationships between soil factors, Quercus robur health, Collybia fusipes root infection and Phytophthora presence, Ann. For. Sci. 60 (2003) 419-426.

[5] Côté W.A., Allen D.C., Biology of the two-lined chestnut borer, Agrilus bilineatus, in Pennsylvania and New York, Ann. Entomol. Soc. Am. 73 (1980) 409-413.

[6] Donaubauer E., Die bedeutung von Krankheitserregern beim gegenwärtigen Eichensterben in Europa - eine Literaturübersicht, Eur. J. For. Pathol. 28 (1998) 91-98.

[7] Dunbar D.M., Stephens G.R., Association of twolined chestnut borer and shoestring fungus with mortality of defoliated oak in Connecticut, For. Sci. 21 (1975) 169-174.

[8] Dunn J.P., Potter D.A., Kimmerer T.W., Carbohydrate reserves, radial growth, and mechanisms of resistance of oak trees to phloemboring insects, Oecologia 83 (1990) 458-468.

[9] Gibbs J.N., Greig B.J.W., Biotic and abiotic factors affecting the dying back of pedunculate oak, Quercus robur L., Forestry 70 (1977) 399-406.

[10] Haack R.A., Acciavatti R.E., Twolined Chestnut Borer, USDA Forest Service, Forest Insect \& Disease Leaflet 168 (1992) 1-8.

[11] Haack R.A., Benjamin D.M., The biology and ecology of the twolined chestnut borer, Agrilus bilineatus (Coleoptera: Buprestidae), on oaks, Quercus spp., in Wisconsin, Can. Entomol. 114 (1982) 385-396.

[12] Hämmerli F., Stadler B., Eichenschäden: Eine Übersicht zur Situationen in Europa und in der Schweiz, Schweiz. Z. Forstw. 140 (1989) 357-374.

[13] Hartmann G., Blank R., Winterfrost, Kahlfraß und Prachtkäferbefall als Faktoren im Ursachenkomplex des Eichensterbens in Norddeutschland, Forst u. Holz 47 (1992) 443-452.

[14] Hartmann G., Kontzog H.G., Beurteilung des Gesundheitszustandes von Alteichen in vom "Eichensterben" geschädigten Beständen Anleitung zur Durchführung von Sanitärhieben gegen Eichenprachtkäfer (Agrilus biguttatus), Forst u. Holz 49 (1994) 216-217.

[15] Kaus A., Schmitt V., Simon A., Wild A., Microscopical and mycological investigations on wood of pedunculate oak (Quercus robur L.) relative to the occurrence of oak decline, J. Plant Phys. 148 (1996) 302-306.

[16] Kozlowski T.T., Carbohydrate sources and sinks in woody plants, Bot. Rev. 58 (1992) 107-222.

[17] Malaisse F., Burgeon D., Degreef J., Deom B., Van Doren V., Le dépérissement des chênes indigènes en Europe Occidentale, Note 1. Symptômes de perte de vitalité, Belg. J. Bot. 126 (1993) 191-205.

[18] Manion P.D., Tree disease concepts, Prentice Hall, New Jersey, 1991, $402 \mathrm{p}$.

[19] Mattson W.J., Haack R.A., The role of drought in outbreaks of plant-eating insects, BioScience 37 (1987) 110-118.

[20] Mihajlovic L., Ristic M., Markovic C., Impact of insect pests on oak decline in Serbia, Proceeding book of the 3rd ICFWST, 1997, pp. 119-125

[21] Moraal L.G., Hilszczanski J., The oak buprestid beetle, Agrilus biguttatus (F.) (Col., Buprestidae), a recent factor in oak decline in Europe, J. Pest Sci. 73 (2000) 134-138. 
[22] Nichols J., Oak mortality in Pennsylvania - A ten-year study, J. For. 66 (1968) 681-694.

[23] Noel A.R., The girdled tree, Bot. Rev. 36 (1970) 162-195.

[24] Parmeter J.R., Kuntz J.E., Riker A.J., Oak wilt development in Bur Oaks, J. Ecol. 46 (1956) 423-435.

[25] Richir O., Le dépérissement des chênes, Bull. Soc. Centr. For. Belg. 17 (1910) 182-190, 252-261.

[26] Schaufuss C., Calwer's Käferbuch - Einführung in die Kenntnis der Käfer Europas, Band I, E. Schweizerbart'sche Verlagsbuchbehandlung, 1916, pp. 699-703.

[27] Schlag M.G., Oak decline in Europe and its causes as seen from a phytopathological point of view, Centralbl. Ges. Forstw. 111 (1992) 243-266.

[28] Schopf A., Rinden- und holzbrütende Schädlinge an erkrankten Eichen in Österreich, Österr. Forstz. 1 (1992) 33-35.

[29] Schwerdtfeger F., Die Waldkrankheiten - Ein Lehrbuch der Forstpathologie und des Forstschutzes, Verlag Paul Parey, HamburgBerlin, 1981, pp. 162-164.
[30] Skadow K., Traue H., Untersuchungsergebnisse zum Vorkommen einer Eichenerkrankung im nordöstlichen Harzvorland, Beitr. Forstwirtsch. 20 (1986) 64-74.

[31] Steiner K.C., A decline-model interpretation of genetic and habitat structure in oak populations and its implications for silviculture, Eur. J. For. Pathol. 28 (1998) 113-120.

[32] Stewart C.M., Excretion and heartwood formation in living trees, Science 153 (1966) 1068-1074.

[33] ICP Forests, Manual on methodologies and criteria for harmonised sampling, assessment, monitoring and analysis of the effects of air pollution on forests, UN-ECE, Hamburg, 1989, 88 p.

[34] Wargo P.M., Armillariella mellea and Agrilus bilineatus and mortality of defoliated oak trees, For. Sci. 23 (1977) 485-492.

[35] Wargo P.M., Consequences of environmental stress on oak: predisposition to pathogens, Ann. Sci. For. 53 (1996) 359-368.

[36] Wargo P.M., Houston D.R., LaMadeleine L.A., Oak decline. USDA Forest Service, Forest Insect \& Disease Leaflet 165 (1983) 1-7. 